\title{
Local Financing Difficulties and Wide Gaps in Credit Access: Growing pessimism on the ground
}

Jean-François Di Meglio

Translator. Peter Brown

\section{(2) OpenEdition}

1 Journals

Electronic version

URL: http://journals.openedition.org/chinaperspectives/6123

DOI: 10.4000/chinaperspectives.6123

ISSN: 1996-4617

\section{Publisher}

Centre d'étude français sur la Chine contemporaine

Printed version

Date of publication: 15 March 2013

Number of pages: $97-98$

ISSN: 2070-3449

\section{Electronic reference}




\section{Local Financing Difficulties and \\ Wide Gaps in Credit Access: Growing pessimism on the ground}

\section{Analysis by Jean-François Di Meglio based on:}

- Sun Tao, (1) "Risky and simplistic platforms of local financing options," Zhongguo gaige, 1 October 2012.

- Li Xuenuo and Wang Jing, (2) "Local finances: How to kill the goose that lays golden eggs. Fiscal negotiations and curbs on subsidies," Xin shiji, 27 August 2012.

- Li Xuenuo, Wang Jing, Shen Hu, Wang Li, Deng Hai, Zhu Yishi, and Wang Xiaoqing, (3) "Local governments' huge deficits," Xin shiji, 27 August 2012.

- Li Yuqian, (4) "Mad rhapsody of ten billion yuan in investments," Xin shiji, 31 August 2012.

- Wen Xiu, Zhang Yuzhe, and Huo Kan, (5) "Hundreds of billions in stimulus: Into a black hole?", Xin shiji, 24 September 2012.

- Chen Long, ${ }^{(6)}$ "10,000 billion local financial worries," Caijing, 7 October 2012.

- Zhang Yuzhe and Tian Lin, (7) "Subprime Chinese style," Xin shiji, 22 October 2012.

$\mathrm{T}$ his fascinating series of articles, relatively consistent in their tone, voices shared pessimism regarding a series of stalemates, mainly at the local level, with growth slow-down and contradictions arising between reflation policy and the need to reform fiscal and redistributive practices such as subsidies.

They were written between mid-summer and late autumn 2012, in the context of a declining growth rate (which had slipped below 8 percent) and the announcement (throughout September) of priority projects as part of a new economy-boosting plan that is apparently more ambitious than the one of 2008-2009 (10,000 billion yuan, as against 4,000 billion yuan in 2008-2009), and more innovative and overarching as regards local level financing. All of the articles take note of underlying deficits, the risks stemming from this situation, and the possibility that problems in the economy cannot be resolved. Without openly saying so, they all hint broadly that Chinese competitiveness faces threats from an outdated financial system and the opacity of transfers between the centre and the local levels.

\section{Limited access to modern financing means}

The first article begins with the issue of debt, concentrating on the dispersal of collateralised debt through "local financing platforms" (difang rongzi pingtai 地方融资平台), and comparing the Chinese situation with that of Western countries and Japan. When in need of funding, China has to tap resources much different from those in countries where one can go to markets and use "other people's money" (qiren de qian 其人的钱). Given the status of its currency and the fear of inflation, China issues notes in a cautious fashion and does not issue debt abroad, contrary to the general practice in other parts of the world. The remaining solutions are loans granted by the regulated banking system as well as issuing domestic debt through "platforms" that the author notes have been the subject of "endless discussions (bujue yu er 不绝于耳) since 2009. These platforms have access to loans, especially through the mobilisation of monies backed by the price of land assets belonging to local governments. This means of financing has grown 15-fold in as many years (a 1,500 percent rise to 3,150 billion yuan, or 400 billion euros, in 2012). Meanwhile, local governments' fiscal receipts have only risen by 900 percent.

\section{Risks linked to such changes}

At the outset, the article highlights two types of risks from these parallel changes: "financial risk" (rongzi 融资), in other words credit-worthiness, and "financing risk" (caizheng 财政) pertaining to public finance, clearly relating to the massively increasing ratio of debt. The article notes that the danger from such financing arrangements (backed by land assets) is mitigated to the extent that abundant land supply (unlike the situation in the West and in Japan) helps ensure a steady growth rate for local debt. Furthermore, this debt is "guaranteed" until 2021, as the central government could float more debt to refinance the repayment needs of local entities, and especially because the Chinese economy's rate of growth, although lower now, remains higher than the rise in debt flotation rate. The article also minimises the risks from a rise in bad debt by mentioning an "optimistic" ratio of 6 percent GDP growth as it concerns four major banks, as against 14 percent in 2000. ${ }^{(8)}$ However, the text clearly shows that the criteria for issuing and managing local debt are a source of concern regarding the actual rise in the

\footnotetext{
. Senior International Monetary Fund economist.

Journalists at Caixin

Journalists at Caixin

Journalist at Caixin

Journalists at Caixin.

6. Professor of finance at the Yangtze River Business School, academic director of the MBA programme, director of the research centre on asset valuation.

7. Journalists at Caixin

8. Going by international criteria, this is important, regardless of the size and performance of Chinese banks, as well as of the standard debt ratio/banks' total assets, the total varying in relation to GNP depending on monetary policy.
} 
quality of asset guarantees in real terms, the parameters of allocating rights issues (based on the total debt), and the quality of projects funded from this debt. By way of comparison - and what makes the situation scary the article points to the discrepancy between tax receivables and budgetary expenditures in 20 provinces or regions (Guangxi being the only "virtuous" region) at levels similar to that of Greece.

The article's recommendations, other than those concerning the exposure of the Chinese currency to international market forces, basically involve a more rigorous approach to transfers between central and local administrations and reforming the fiscal regime to render it more efficient.

\section{"Killing the goose that lays the golden egg"}

Another of the critical points developed in the second article invokes a well-known proverbial expression or chengyu, “临水而渔" (linshui er yu), that is to say, "draining the pond to catch fish," or "killing the goose that lays the golden egg."

This article highlights the contradictions faced while boosting the efficiency of tax collection, based on a survey and interviews with entrepreneurs and on-site examples. There have been several cases of governmental debt in arrears, manipulation of value added tax, and fiddling with figures. Even so, the article argues, tightening tax pressure carries the risk of increasing tax evasion and endangering the dynamism of enterprises. Instances of tax forgiveness for units with revenues less than 20,000 yuan, as well as examples of enterprises that have already accumulated arrears from major clients, show that steps taken to increase fiscal pressure or to revise arrangements for "negotiations" on the VAT rate or conditions of collection could hurt growth. Numerous examples from the high-tech world or the cartoon and computer-assisted film industry point to the preservation of exceptions and of "niches" in the Chinese economy to forestall the killing of all the "geese that lay golden eggs," such as Taiwanese firms installed in Dongguan for more than two decades as well as LED manufacturers or sub-contractors of CCTV. ${ }^{(9)}$

\section{Local reflation policies are less justifiable than in 2008-2009}

The third and fourth articles deal with the widening gap between the tax revenues and expenditures of local entities. Even at the national level, expenditures have risen 19 percent while collection of taxes has increased by only 12 percent. It is therefore possible that budget expansion has opened a real risk in a situation where the alleged reasons underlying the reflation plan (less impressive according to the articles) of 4,000 billion yuan in 20082009 (as opposed to the 10,000 billion yuan this time) are no longer sustainable: four years ago, the aim was to reboot a slowing economy from the top at a time. There was greater investment than initially foreseen and at the same time, in an unfavourable climate, municipalities have been independently launching five-year plans or infrastructure investment programmes, as in Guangdong, Tianjin, Shanxi, Chongqing, Fujian, and Guizhou. Guangdong governor Zhu Xiaodan reportedly called for reversing the decline in investment dynamism and proposed 19 measures to speed up construction of major projects, including those in chemical products, steel works, and advanced technology products. Chongqing municipality has put out a three-year plan for revitalising major industries with investments totalling 1.5 billion yuan. Xi'an has unveiled a programme to build new metro lines, and Guizhou will launch a three billion yuan plan for tourism development.

\section{"Where will the money come from?"}

The fifth and sixth articles take it from there and emphasise the doubts and hesitations surrounding "the unknown and the risk, the faith and hope" (weizhi he fengxian, xinxin he xiwang 未知和风险, 信心和希望) that characterise this new wave of investment, the funding sources of which are far from clear (hence the title of the fifth article: "Where will the money come from?"). "The issue of poor return on investment" (huibaolü di de wenti 回 报率低的问题) is also raised. The seventh article brings together a number of reactions ranging from sarcasm to perplexity over the current orientations and contradictions in public finance, and borrowings based on platforms linked to land asset guarantees ("collateralised loans" deemed "Chinesestyle subprime" (zhongshi cizi 中式次贷). Making reference to the 'shadow banking' system while stressing that its sophistication and securitisation fall short of levels in the United States, the article raises the issue of the glaring lack of steps aimed at checking the quality of credit issued and assessing the "sub-contractors" on whom new debt creation depends. The article, based on field investigation and solicitation of opinions, is also downbeat on the evolution of this class of financial assets.

With different approaches, the articles thus provide a well-documented and unanimous view on an increasingly important aspect of the Chinese economy and its financial dimension, based on the same type of critical analysis as that originating from outside, and echoing profound doubts over an unreformed part of the economy, although some modest signs of pickup have become evident since the articles were published.

\section{Translated by N. Jayaram.}

